\title{
ANALISIS DAKTILITAS TEXTILE REINFORCED CONCRETE (TRC) DENGAN PERKUATAN SERAT CANTULA (AGAVE CANTULA ROXB)
}

\author{
Stefanus Adi Kristiawan(1), Edy Purwanto(2), Irfan Fathurahman(3) \\ 1) Pengajar Fakultas Teknik, Prodi Teknik Sipil, Universitas Sebelas Maret \\ 2) Pengajar Fakultas Teknik, Prodi Teknik Sipil, Universitas Sebelas Maret \\ 3) Mahasiswa Fakultas Teknik, Prodi Teknik Sipil, Universitas Sebelas Maret
}

\section{Jl. Ir. Sutami 36A, Surakarta 57126; Telp.0271-634524.Indonesia, email: mrfathurahmanirfan@gmail.com}

\begin{abstract}
Abstrak. Beton merupakan salah satu bahan konstruksi yang paling umum digunakan saat ini. Beton memiliki beberapa kerugian seperti kuat tarik yang rendah, perawatan beton segar yang cukup sulit dan bersifat getas. Sifat getas pada beton inilah yang harus ditanggulangi dengan penambahan tulangan untuk memberikan kekuatan dan daktilitas yang diperlukan beton untuk menopang beban struktur dan salah satu jalan keluarnya adalah menggunakan TRC. Textile reinforced concrete (TRC) adalah beton yang mengganti tulangan dengan suatu serat, serat yang digunakan adalah serat alami. Kelebihan yang dimiliki oleh serat cantula itu sendiri diantaranya yaitu harga murah, dapat diuraikan oleh alam, mudah di dapat (producible), kuat, ringan dan kemampuan mekanik yang tinggi (Kurniawan Indra P, Wijang Wisnu Raharjo, 2015). TRC diaplikasikan sebagai confinement concrete pada silinder beton untuk mengetahui pengaruh anyaman serat cantula dengan berbagai variasi pada kuat tekan beton. Textile Reinforced Concrete (TRC) pada penelitian ini terdiri dari matriks berupa silinder beton dengan dimensi diameter dan tinggi sebesar $75 \mathrm{~mm}$ dan $150 \mathrm{~mm}$. Reinforcement berupa anyaman serat cantula yang direkatkan dengan Polymer Modified Mortar kemudian dikekangkan pada beton. Anyaman serat cantula memiliki variasi arah penulangan aksial sesuai dengan dimensi $10 \mathrm{~mm} \times 10 \mathrm{~mm}, 10 \mathrm{~mm}$ x $15 \mathrm{~mm}, 10 \mathrm{~mm}$ x $20 \mathrm{~mm}, 15 \mathrm{~mm}$ x $10 \mathrm{~mm}, 20 \mathrm{~mm} \times 10 \mathrm{~mm}$. Variasi anyaman tersebut digunakan untuk mengetahui nilai daktilitas dan serapan energi dalam hal ini toughness. Pengujian pada TRC dilakukan pada umur 28 hari. Hasil penelitian penggunaan serat cantula yang dianyam untuk perkuatan meningkatkan nilai daktilitas dari beton normal. Peningkatan nilai daktilitas dalam \% dari nilai terendah berturut-turut: TRC-100, TRC-150, TRC-002, TRC-200 dan TRC-051 adalah berturut-turut: 26,79\%; 30\%; 30,42\%; 31,09\% dan 37,06\%. Nilai Toughness mengalami peningkatan dalam \% dari nilai terendah berturut-turut: TRC-002, TRC-100, TRC-051, TRC-200 dan TRC-150 adalah berturut-turut: $24,1 \% ; 28,7 \% ; 39,2 \% ; 40,2 \%$ dan $41,1 \%$. Hal ini menunjukkan bahwa pengekangan anyaman serat cantula memberi pengaruh yang cukup signifikan membuat beton lebih daktail dan persebaran energinya meningkat.
\end{abstract}

Kata Kunci : TRC, Textile Reinforced Concrete, Serat Cantula, Kuat Tekan, Daktilitas

\begin{abstract}
Concrete is one of the most commonly used construction materials today. Concrete has several disadvantages such as low tensile strength, maintenance of fresh concrete which is quite difficult and brittle. This brittle nature of the concrete must be overcome by adding reinforcement to provide the strength and ductility needed by the concrete to support the load structure and one way out is to use TRC. Textile reinforced concrete $(T R C)$ is a concrete that replaces reinforcement with a fiber, the fiber used is natural fiber. The advantages possessed by the fiber canula itself include low prices, can be deciphered by nature, easily (producible), strong, light and high mechanical ability (Kurniawan Indra P, Wijang Wisnu Raharjo, 2015). TRC is applied as concrete confirmation on concrete cylinders to determine the effect of cantula fiber webbing with various variations on concrete compressive strength Textile Reinforced Concrete (TRC) in this study consisted of a matrix in the form of a concrete cylinder with dimensions of diameter and height of $75 \mathrm{~mm}$ and $150 \mathrm{~mm}$. Reinforcement in the form of woven fiber fibers glued together with Polymer Modified Mortar is then tightened to the concrete. Woven fiber cannula has a variety of axial reinforcement directions according to dimensions of $10 \mathrm{~mm}$ $\times 10 \mathrm{~mm}, 10 \mathrm{~mm} \times 15 \mathrm{~mm}, 10 \mathrm{~mm} \times 20 \mathrm{~mm}, 15 \mathrm{~mm} \times 10 \mathrm{~mm}, 20 \mathrm{~mm} \times 10 \mathrm{~mm}$. The webbing variation is used to determine the value of ductility and energy uptake in this case toughness. Testing on TRC is done at 28 days. The results of the study on the use of weaved fiber for reinforcement increase the ductility value of normal concrete. Increasing the ductility value in\% of the lowest value in a row: TRC-100, TRC-150, TRC-002, TRC-200 and TRC-051 are: 26.79\%; 30\%; 30.42\%; 31.09\% and 37.06\%. Toughness values have increased in $\%$ of the lowest values in a row: TRC-002, TRC-100, TRC-051, TRC-200 and TRC-150 are respectively: $24.1 \% ; 28.7 \% ; 39.2 \% ; 40.2 \%$ and $41.1 \%$. This shows that the restraint of the cantula fiber webbing has a significant influence on making the concrete more ductile and the energy distribution increases.
\end{abstract}

Keyword : TRC, Textile Reinforced Concrete, Cantula Fiber, Ductility, Toughness

\section{PENDAHULUAN}

Beton merupakan salah satu bahan konstruksi yang paling umum digunakan saat ini. Keuntungan penggunaan beton untuk struktur gedung, jalan raya, bendungan dan lainnya adalah karena beton mudah dibentuk sesuai kebutuhan arsitektur, masa layan beton yang panjang, dan relatif murah. Namun juga beton memiliki beberapa kerugian seperti kuat tarik yang rendah, perawatan beton segar yang cukup sulit dan bersifat getas. Sifat getas pada beton inilah yang harus ditanggulangi dengan penambahan tulangan untuk memberikan kekuatan dan daktilitas yang diperlukan beton untuk menopang beban struktur. 
Seiring berjalannya waktu kerusakan yang timbul akibat beban yang menerpa struktur secara axial maupun lateral membuat daktilitas beton mengalami penurunan. Treatment dibutuhkan untuk menjaga kekuatan struktur terjaga, salah satunya adalah dengan memberi perkuatan tambahan dibagian luar beton yang rusak. Pada umumnya pemberian kekangan pada beton menggunakan bahan seperti carbon dan sejenisnya yang mana memakan cukup banyak biaya. Muncul bahan-bahan alternatif yang dibutuhkan sebagai pengganti bahan kekangan yang lebih ramah lingkungan dan tentunya memiliki kekuatan yang dirasa akan cukup untuk mengganti bahan konvensional yang ada saat ini.

Jenis-jenis beton saat ini beragam macam untuk menanggulangi post-failure. Salah satunya adalah textile reinforced concrete. Penelitian ini akan membahas tentang textile reinforced concrete (TRC). Textile reinforced concrete (TRC) adalah beton yang mengganti tulangan dengan suatu serat, serat yang digunakan adalah serat alami. Kelebihan yang dimiliki oleh serat cantula itu sendiri diantaranya yaitu harga murah, dapat diuraikan oleh alam, mudah di dapat (producible), kuat, ringan dan kemampuan mekanik yang tinggi (Kurniawan Indra P, Wijang Wisnu Raharjo, 2015). Hasil survey dari Badan Penilitian dan Pengembangan Industri Departemen Perindustrian Yogyakarta, menyatakan bahwa cantula mempunyai kandungan selulose 64,3\% sehingga serat ini berpotensi sebagai bahan penguat komposit (Raharjo dkk., 2015).

Berdasarkan pertimbangan-pertimbangan dari atas, maka penelitian ini akan menguji textile reinforced concrete (TRC) dengan matrik berupa silinder beton dan reinforcement berupa anyaman serat cantula. TRC diaplikasikan sebagai confinement concrete pada silinder beton untuk mengetahui nilai daktilitas dan serapan energinya.

\section{LANDASAN TEORI}

\section{Karakteristik Textile Reinforced Concrete (TRC)}

Sebagaimana diketahui bahwa kolom merupakan elemen struktur yang penting karena kegagalan kolom akan berakibat langsung terhadap komponen struktur lainnya. Menurut Karimah dan Wahyudi (2010) bahwa penurunan daktilitas dan energi disipasi pada kolom beton bertulang disebabkan oleh jarak spasi sengkang yang semakin renggang dan peningkatan beban aksial yang bekerja pada kolom. Hal ini menunjukan bahwa kekangan tambahan dibutuhkan untuk menjaga daktilitas struktur tersebut.

penelitian ini akan menguji textile reinforced concrete (TRC) dengan reinforcement berupa anyaman serat cantula dengan mortar yang akan diuji 28 hari. Serat pada reinforcement memiliki kontribusi peranan penting dalam komposit, karena berfungsi sebagai penguat serta meningkatkan kekuatan tarik (lebih daktail) dibandingkan dengan beton pada umumnya.

\section{Uji Tekan}

Menurut SNI 03-1974-2011 kuat tekan beton adalah besarnya beban per satuan luas, yang dapat menyebabkan benda uji yang berupa beton hancur. Beban tersebut berupa gaya tekan yang dihasilkan oleh mesin tekan. Untuk benda uji berbentuk silinder mempunya nilai konversi 0,83 . Benda uji yang digunakan pada penelitian ini adalah silinder dengan diameter $75 \mathrm{~mm}$ dan panjang $150 \mathrm{~mm}$.

Perhitungan kuat tekan beton diperoleh berdasarkan rumus :

$$
\mathrm{fc}=\frac{P}{A}
$$

Dimana

fc $\quad=$ kuat tekan beton $(\mathrm{MPa})$

$\mathrm{P} \quad=$ beban maksimum total $(\mathrm{N})$

A $\quad=$ luas dari permukaan yang dibebani $\left(\mathrm{mm}^{2}\right)$

\section{Daktilitas}

Faktor daktilitas $(\mu)$ adalah rasio antara luasan total dibawah kurva perbandingan gaya dan deformasi dengan luasan pada saat leleh pertama dibawah kurva perbandingan gaya dan deformasi, seperti ditunjukan pada persamaan dibawah ini:

$$
\mu=\frac{\Delta u}{\Delta y}
$$

Dimana :

$\mu \quad=$ daktilitas.

$\Delta \mathrm{u} \quad=$ lendutan ultimate pada grafik beban-lendutan

$\Delta \mathrm{y} \quad=$ lendutan leleh pertama pada grafik beban-lendutan

\section{Toughness}


Toughness adalah kemampuan suatu benda untuk menyerap energi dan dapat dihitung dari luas di bawah diagram hubungan beban - lendutan. Hal ini menunjukkan seberapa besar kemampuannya untuk menyebarkan secara merata energi yang diterima akibat pembebanan. Untuk mendapatkan nilai toughness digunakan perhitungan luas daerah dibawah grafik hubungan beban - lendutan. Data-data yang diperoleh dari hasil percobaan diplotkan pada grafik dan dicari regresinya. Hasil dari regresi tersebut merupakan persamaan grafik P (D) dan diberi lambang $\mathrm{f}(\mathrm{x})$. Dari grafik $\mathrm{f}(\mathrm{x})$ tersebut bisa diperoleh luas daerah yang merupakan nilai dari index of tonghness. Luas daerah yang dimaskud merupakan luas daerah di bawah grafik $\mathrm{f}(\mathrm{x})$ yang dibatas oleh nilai a dan $\mathrm{b}$. Nilai a dari grafik tersebut mempunyai koordinat $(0,0)$ yang merupakan awal pengujian, dimana benda uji belum mengalami defleksi. Sedangkan nilai b yang membatasi luas daerah sebelah kanan grafik merupakan besar defleksi yang terjadi sebesar 0,85 dari lendutan puncak.

\section{METODE}

\section{Material}

Material utama pada textile reinforced concrete berupa komposit yang terdiri dari tekstil yang berfungsi sebagai reinforcement dan fine-grained concrete digunakan sebagai matriks. Bahan-bahan yang perlu dipersiapkan untuk matriks dalam penelitian antara lain.

1. Agregat halus yang digunakan adalah pasir yang memenuhi syarat lolos saringan $1,18 \mathrm{~mm}$.

2. Agregat kasar yang digunakan adalah batu pecah yang memiliki ukuran maksimum $20 \mathrm{~mm}$.

3. Semen dengan jenis Pozzolan Portland (PPC).

4. Anyaman serat cantula, dengan variasi anyaman $10 \mathrm{~mm} \times 10 \mathrm{~mm}, 10 \mathrm{~mm} \times 15 \mathrm{~mm}, 10 \mathrm{~mm} \times 20 \mathrm{~mm}$.

5. Superplasticizer yang digunakan adalah Master Glenium ${ }^{\circledR}$ ACE 8595 yang diproduksi oleh PT. BASF Indonesia. Superplasticizer ini untuk meningkatkan flowability dan menambahkan sifat daktail pada mortar.

6. Accelerator SIKACIM® Accelerator sebanyak $50 \%$ dari jumlah air yang digunakan untuk membuat benda uji. Accelerator berguna untuk mempercepat pengerasan pada mortar dan meningkatkan kekuatan mortar pada umur awal.

7. Polimer Bonding Adhesive dari PT Ingus Badak. Polimer berguna sebagai perekat antara mortar dengan serat cantula.

\section{Benda Uji}

Benda uji yang digunakan pada penelitian ini berupa silinder beton dengan diameter $75 \mathrm{~mm}$ dan tinggi $150 \mathrm{~mm}$. Pengujian benda uji dilakukan dengan cara tekan langsung pada umur 28 hari dengan menggunakan UTM. Reinforcement yang digunakan adalah anyaman serat cantula yang di tempelkan ke beton menggunakan Polymer Modified Mortar (PMM). Varisasi matriks yang diuji berupa anyaman serat cantula pada textile reinforced concrete (TRC). Variasi anyaman serat cantula yang akan diteliti yaitu $10 \mathrm{~mm} \times 10 \mathrm{~mm}, 10 \mathrm{~mm} \times 15 \mathrm{~mm}, 10 \mathrm{~mm} \times 20 \mathrm{~mm}$, $15 \mathrm{~mm} \times 10 \mathrm{~mm}, 20 \mathrm{~mm} \times 10 \mathrm{~mm}$.

\section{HASIL DAN PEMBAHASAN}

Uji Kuat Tekan

Rekapitulasi hasil uji kuat tekan dapat dilihat pada Tabel 4.1 dibawah ini.

Tabel 1 Hasil Uji Kuat Tekan Aktual TRC dengan Anyaman Serat Cantula

\begin{tabular}{cccccc}
\hline KODE & $\mathbf{P}(\mathbf{k N})$ & $\mathbf{d}(\mathbf{m m})$ & $\mathbf{A}\left(\mathbf{m m}^{2}\right)$ & $\mathbf{f} \mathbf{c}(\mathbf{M P a})$ & f'c rata-rata $(\mathbf{M P a})$ \\
\hline TRC-000-A & 72,5 & 75 & 4419,64 & 16,40 & \\
TRC-000-B & 75 & 75 & 4419,64 & 16,96 & 17,98 \\
TRC-000-C & 67,5 & 75 & 4419,64 & 15,27 & \\
TRC-000-D & 102,5 & 75 & 4419,64 & 23,19 & \\
TRC-000-E & 80 & 75 & 4419,64 & 18,10 & \\
TRC-100-A & 72,5 & 75 & 4419,64 & 16,40 & 18,32 \\
TRC-100-B & 90 & 75 & 4419,64 & 20,36 & \\
TRC-100-C & 75 & 75 & 4419,64 & 16,96 & \\
\hline
\end{tabular}




\begin{tabular}{lccccc}
\hline TRC-100-D & 95 & 75 & 4419,64 & 21,49 & \\
TRC-100-E & 72,5 & 75 & 4419,64 & 16,40 & 19,79 \\
TRC-150-A & 77,5 & 75 & 4419,64 & 17,53 & \\
TRC-150-B & 95 & 75 & 4419,64 & 21,49 & \\
TRC-150-C & 100 & 75 & 4419,64 & 22,62 & \\
TRC-150-D & 95 & 75 & 4419,64 & 21,49 & 20,25 \\
TRC-150-E & 70 & 75 & 4419,64 & 15,83 & \\
TRC-200-A & 102,5 & 75 & 4419,64 & 23,19 & \\
TRC-200-B & 72,5 & 75 & 4419,64 & 16,40 & \\
TRC-200-C & 77,5 & 75 & 4419,64 & 17,53 & 19,11 \\
TRC-200-D & 92,5 & 75 & 4419,64 & 20,92 & \\
TRC-200-E & 102,5 & 75 & 4419,64 & 23,19 & \\
TRC-051-A & 70 & 75 & 4419,64 & 15,83 & \\
TRC-051-B & 72,5 & 75 & 4419,64 & 16,40 & \\
TRC-051-C & 110 & 75 & 4419,64 & 24,89 & \\
TRC-051-D & 90 & 75 & 4419,64 & 20,36 & \\
TRC-051-E & 80 & 75 & 4419,64 & 18,11 & \\
TRC-002-A & 80 & 75 & 4419,64 & 18,11 & \\
TRC-002-B & 67,5 & 75 & 4419,64 & 15,27 & \\
TRC-002-C & 85 & 75 & 4419,64 & 19,22 & \\
TRC-002-D & 72,5 & 75 & 4419,64 & 16,40 & \\
TRC-002-E & 75 & 75 & 4419,64 & 16,96 & \\
\hline
\end{tabular}

Hasil Uji Kuat Tekan TRC dengan Anyaman Serat Cantula

Dari tabel diatas dapat diketahui bahwa nilai kuat tekan paling tinggi terdapat pada TRC 200 yaitu sebesar 20,2505 MPa. Hal ini dikarenakan anyaman pada arah aksial pada TRC 200 lebih renggang daripada TRC 100 dan TRC 150. Sedangkan nilai kuat tekan paling rendah terdapat pada TRC 000 yang merupakan beton normal atau beton tidak terkekang. Hal ini dikarenakan TRC 000 tidak mendapatkan reinforcement.

\subsection{Analisis Daktilitas}

Hasil pengujian daktilitas beton dengan variasi jarak anyaman serat cantula diolah dalam bentuk grafik dan tabel beban - lendutan agar di dapat kuat tekan ultimate dan leleh pertama untuk mendapatkan data nilai daktilitas. Contoh grafik hubungan beban - lendutan disajikan berikut : 


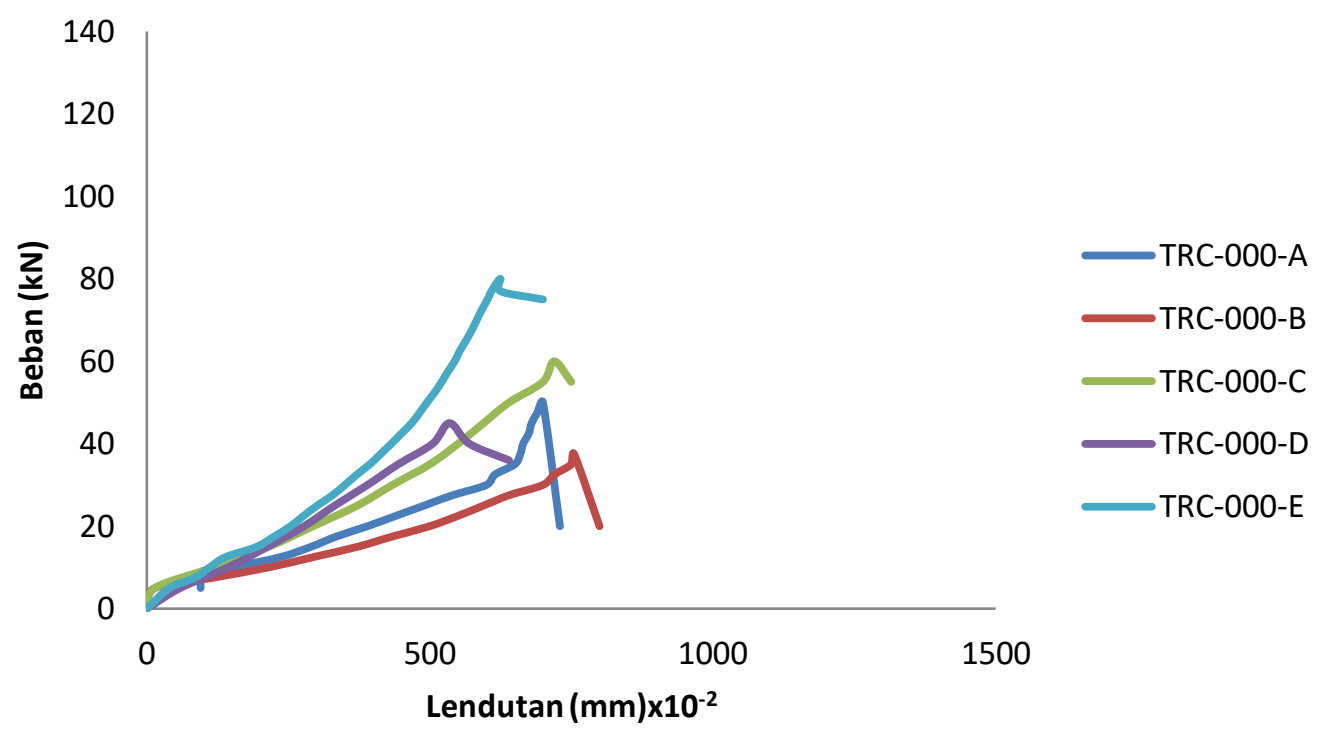

Gambar 1 Grafik beban - lendutan beton normal

Dari grafik di atas dapat dihitung perbandingan lendutan optimum dengan lendutan leleh pertama. Maka nilai daktilitas dapat dicari dengan persamaan berikut

Daktilitas $=(\Delta$ Ultimate $) /(\Delta$ Leleh 1$)$

Sebagai salah satu contoh perhitungan daktilitas diambil dari data benda uji TRC-000-A sebagai berikut :

$\Delta$ Ultimate $=700 \mathrm{~mm} \times 10-2$

$\Delta$ Leleh pertama $=236 \mathrm{~mm} \times 10-2$

Maka daktilitas yang diperoleh adalah :

Daktilitas $=700 / 236=2,966$

Untuk perhitungan benda uji yang lain dapat dilihat dalam Tabel 4.2 berikut :

Tabel 2 Analisis Nilai Daktilitas

\begin{tabular}{ccccc}
\hline Kode benda uji & $\boldsymbol{\Delta y}$ & $\boldsymbol{\Delta u}$ & Daktilitas & Rata-rata \\
\hline TRC-000-A & 236 & 700 & 2.966 & \\
TRC-000-B & 215 & 755 & 3.512 & \\
TRC-000-C & 215 & 720 & 3.349 & $\mathbf{3 . 6 1 3}$ \\
TRC-000-D & 143 & 535 & 3.741 & \\
TRC-000-E & 139 & 625 & 4.496 & \\
TRC-100-A & 116 & 618 & 5.328 & \\
TRC-100-B & 175 & 851 & 4.863 & \\
TRC-100-C & 122 & 450 & 3.689 & $\mathbf{4 . 9 3 5}$ \\
TRC-100-D & 115 & 688 & 5.983 & \\
TRC-100-E & 139 & 669 & 4.813 & \\
TRC-150-A & 244 & 810 & 3.320 & \\
TRC-150-B & 104 & 724 & 6.962 & \\
TRC-150-C & 118 & 840 & 7.119 & $\mathbf{5 . 1 6 1}$ \\
TRC-150-D & 165 & 700 & 4.242 & \\
TRC-150-E & 152 & 633 & 4.164 & \\
TRC-200-A & 181 & 797 & 4.403 & $\mathbf{5 . 2 4 3}$ \\
TRC-200-B & 183 & 815 & 4.454 & \\
\hline
\end{tabular}




\begin{tabular}{ccccc}
\hline TRC-200-C & 84 & 700 & 8.333 & \\
TRC-200-D & 133 & 674 & 5.068 & \\
TRC-200-E & 192 & 760 & 3.958 & \\
TRC-051-A & 118 & 612 & 5.186 & \\
TRC-051-B & 82 & 565 & 6.890 & \\
TRC-051-C & 144 & 940 & 6.528 & $\mathbf{5 . 7 4 0}$ \\
TRC-051-D & 124 & 740 & 5.968 & \\
TRC-051-E & 158 & 652 & 4.127 & \\
TRC-002-A & 132 & 656 & 4.970 & \\
TRC-002-B & 114 & 630 & 5.526 & \\
TRC-002-C & 104 & 692 & 6.654 & $\mathbf{5 . 1 9 2}$ \\
TRC-002-D & 145 & 672 & 4.634 & \\
TRC-002-E & 170 & 710 & 4.176 & \\
\hline
\end{tabular}

Dari Tabel 2 di atas dapat digambarkan sebuah grafik yang menggambarkan hubungan pengaruh variasi anyaman terhadap nilai daktilitas yang tersaji dalam Gambar 2 berikut ini :

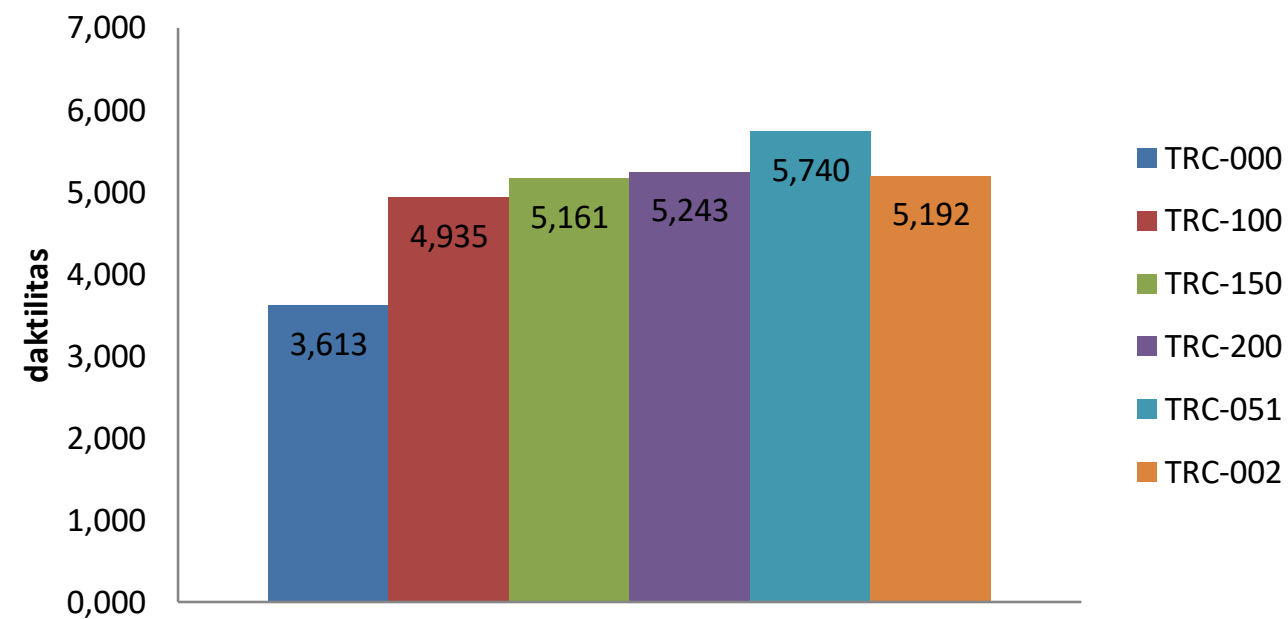

Analisis Toughness

Gambar 2 Hubungan Daktilitas dengan Variasi Anyaman

Hasil pengujian index of toughness beton terkekang dengan variasi anyaman serat cantula diolah dalam bentuk grafik beban - lendutan agar didapat suatu persamaan untuk menentukan luasan daerah dibawah kurva. 


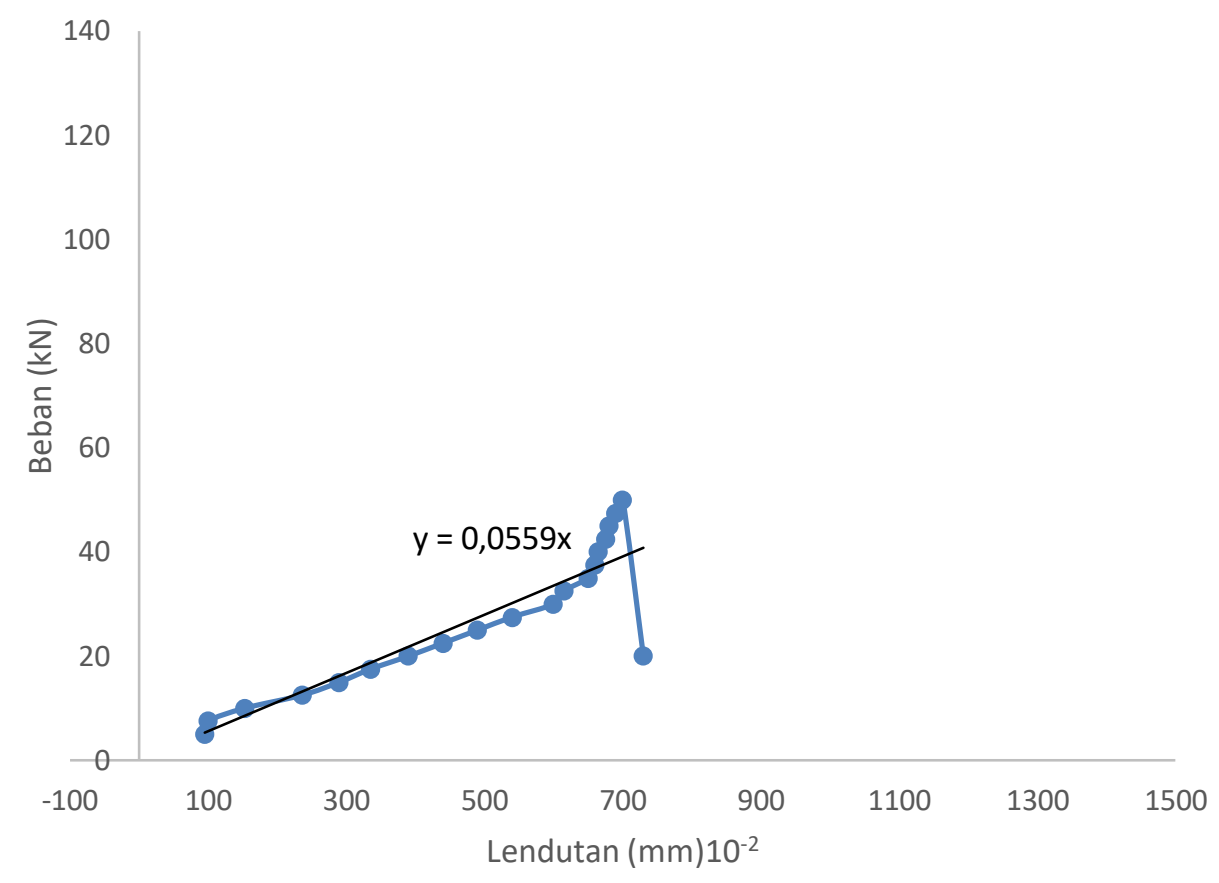

Gambar 3 Grafik Index of Toughness TRC-000-A

Dari grafik ini dapat dihitung luas bidang bawah grafik tersebut. Maka nilai toughness dapat dicari dengan rumus:

Toughness $=\int_{a}^{b} f(x) d x$

Dimana : $\mathrm{f}(\mathrm{x})=$ hasil regresi linier dari persamaan grafik beban - lendutan

a $=$ defleksi belum terjadi

$\mathrm{b}=$ defleksi ultimate beton

Sebagai salah satu contoh analisa perhitungan nilai toughness diambil dari data benda uji TRC-000-A,

Dari hasil pengujian didapat :

$\mathrm{f}(\mathrm{x})=\mathrm{y}=0,0559 \mathrm{x}$

$\mathrm{a}=0$

$\mathrm{b}=625 \mathrm{~mm} \times 10^{-2}$

Dari hasil perhitungan diperoleh nilai toughness $10918 \mathrm{kNmm}^{-4}$

Untuk perhitungan benda uji lain dapat dilihat dalam Tabel 3 berikut :

Tabel 3 Analisis Nilai Toughness

\begin{tabular}{ccccc}
\hline Kode & Persamaan & $\begin{array}{c}\text { Defleksi } \\
\mathbf{m a x} \\
\left(\mathbf{m m}^{-2}\right)\end{array}$ & $\begin{array}{c}\text { Toughness } \\
\left(\mathbf{k N m m} \mathbf{k}^{-4}\right)\end{array}$ & $\begin{array}{c}\text { Toughness } \\
\text { rata-rata } \\
\left(\mathbf{k N m m}^{-4}\right)\end{array}$ \\
\hline TRC-000-A & $\mathrm{y}=0,0559 \mathrm{x}$ & 625 & 10918 & \\
TRC-000-B & $\mathrm{y}=0,0415 \mathrm{x}$ & 800 & 13280 & \\
TRC-000-C & $\mathrm{y}=0,0756 \mathrm{x}$ & 750 & 21263 & 16748 \\
TRC-000-D & $\mathrm{y}=0,723 \mathrm{x}$ & 570 & 11745 & \\
TRC-000-E & $\mathrm{y}=1,083 \mathrm{x}$ & 700 & 26534 & \\
TRC-100-A & $\mathrm{y}=0,1049 \mathrm{x}$ & 618 & 20032 & \\
TRC-100-B & $\mathrm{y}=0,0857 \mathrm{x}$ & 851 & 31032 & \\
TRC-100-C & $\mathrm{y}=0,1443 \mathrm{x}$ & 450 & 14610 & \\
TRC-100-D & $\mathrm{y}=0,1214 \mathrm{x}$ & 688 & 28732 & \\
TRC-100-E & $\mathrm{y}=0,1027 \mathrm{x}$ & 669 & 22982 & \\
TRC-150-A & $\mathrm{y}=0,0859 \mathrm{x}$ & 810 & 28179 & \\
TRC-150-B & $\mathrm{y}=0,1134 \mathrm{x}$ & 724 & 29721 & \\
\hline
\end{tabular}




\begin{tabular}{lclll}
\hline TRC-150-C & $\mathrm{y}=0,1108 \mathrm{x}$ & 840 & 39090 & \\
TRC-150-D & $\mathrm{y}=0,1085 \mathrm{x}$ & 700 & 26583 & \\
TRC-150-E & $\mathrm{y}=0,0927 \mathrm{x}$ & 633 & 18572 & \\
TRC-200-A & $\mathrm{y}=0,1014 \mathrm{x}$ & 797 & 32205 & \\
TRC-200-B & $\mathrm{y}=0,0805 \mathrm{x}$ & 815 & 26735 & \\
TRC-200-C & $\mathrm{y}=0,0982 \mathrm{x}$ & 700 & 24059 & 28011 \\
TRC-200-D & $\mathrm{y}=0,1107 \mathrm{x}$ & 674 & 25144 & \\
TRC-200-E & $\mathrm{y}=0,1105 \mathrm{x}$ & 760 & 31912 & \\
TRC-051-A & $\mathrm{y}=0,1004 \mathrm{x}$ & 612 & 18802 & \\
TRC-051-B & $\mathrm{y}=0,1201 \mathrm{x}$ & 565 & 19169 & \\
TRC-051-C & $\mathrm{y}=0,1068 \mathrm{x}$ & 940 & 47184 & 22560 \\
TRC-051-D & $\mathrm{y}=0,1113 \mathrm{x}$ & 740 & 30474 & \\
TRC-051-E & $\mathrm{y}=0,1043 \mathrm{x}$ & 652 & 22169 & \\
TRC-002-A & $\mathrm{y}=0,103 \mathrm{x}$ & 656 & 22162 & \\
TRC-002-B & $\mathrm{y}=0,0952 \mathrm{x}$ & 630 & 18892 & \\
TRC-002-C & $\mathrm{y}=0,1068 \mathrm{x}$ & 692 & 25571 & 22053 \\
TRC-002-D & $\mathrm{y}=0,0928 \mathrm{x}$ & 672 & 20953 & \\
TRC-002-E & $\mathrm{y}=0,09 \mathrm{x}$ & 710 & 22685 & \\
\hline
\end{tabular}


Dari Tabel 3 di atas dapat digambarkan sebuah grafik yang menggambarkan hubungan pengaruh serat cantula terhadap beton normal tanpa kekangan yang tersaji dalam Gambar 4 berikut ini :

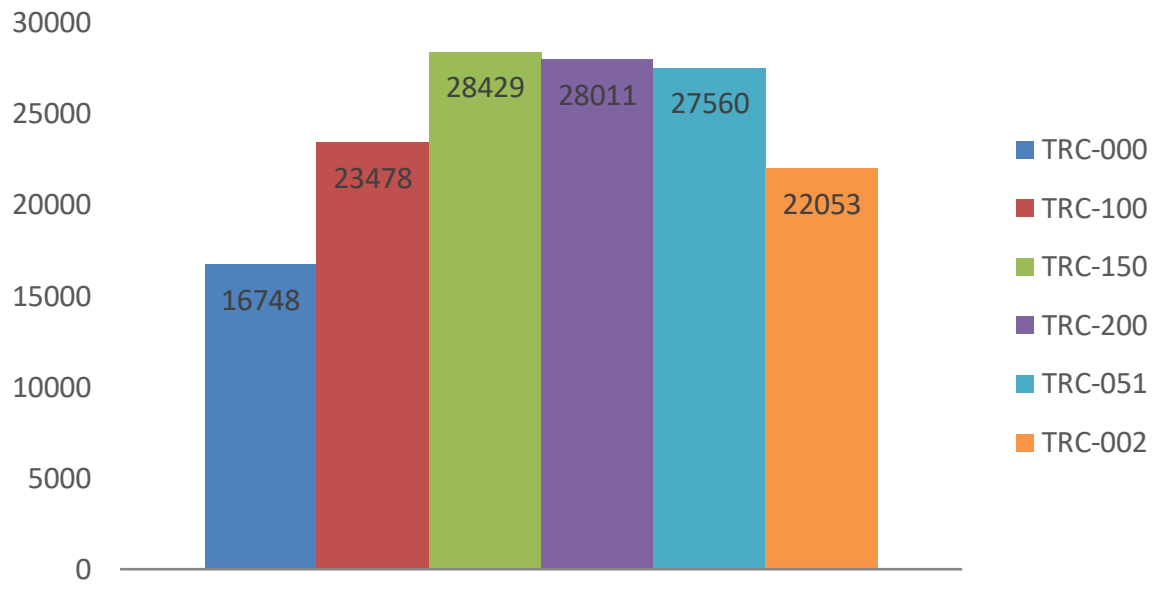

Gambar 4 Grafik Hubungan Toughness dengan Beton Normal

Dari grafik daktilitas dapat diketahui bahwa adanya pengaruh dalam pemberian kekangan serat cantula pada beton normal. Pada variasi anyaman 1 cm dengan kode TRC-100 didapatkan peningkatan daktilitas sebesar 1,322 atau sebesar 26,79\%, pada kode TRC-150 terjadi peningkatan sebesar 1,548 atau sebesar 30\%, dan kode yang memiliki peningkatan paling tinggi dengan kode TRC-051 sebesar 2,127 atau sebesar 37,06\%.

Tabel 4 Peningkatan Nilai Toughness

\begin{tabular}{cccc}
\hline Kode & Daktilitas & Peningkatan & $\begin{array}{c}\text { Prosentase } \\
\text { Peningkatan } \\
\text { (\%) }\end{array}$ \\
\hline TRC-000 & 3,613 & & \\
TRC-100 & 4,935 & 1,322 & 26,79 \\
TRC-150 & 5,161 & 1,548 & 30,00 \\
TRC-200 & 5,243 & 1,630 & 31,09 \\
TRC-051 & 5,74 & 2,127 & 37,06 \\
TRC-002 & 5,192 & 1,579 & 30,42 \\
\hline
\end{tabular}

Kenaikan nilai daktilitas pada beton normal yang dikekang disebabkan oleh serat cantula yang dianyam sehingga membentuk sebuah perkuatan baru untuk beton ditambah dengan PMM yang memperkuat serat cantula dalam menerima beban lateral. Umumnya beton tanpa tulangan akan pecah ketika mendapatkan kuat tekan aksial optimum yang menyebabkan beton akan berdeformasi ke segala arah. Perkuatan lateral oleh serat cantula nyatanya memberi dampak yang signifikan hingga 37\% dalam menerima tegangan yang terjadi dan membuat luas daerah inelastis beton bertambah.

Dari grafik toughness dapat diketahui bahwa terjadi peningkatan pada kode yang diberi perkuatan serat cantula. Pada TRC-100 terjadi peningkatan sebesar 6730 kNmm-4 atau sekitar 28,7\%. Pada TRC-150 terjadi peningkatan tertinggi sebesar $11681 \mathrm{kNmm}-4$ atau sebesar $41,1 \%$.

Tabel 5 Peningkatan Nilai Toughness

\begin{tabular}{rccc}
\hline Kode & $\begin{array}{c}\text { Toughness } \\
\left(\mathbf{k N m _ { m }} \mathbf{H}^{\mathbf{S}}\right.\end{array}$ & Peningkatan & $\begin{array}{c}\text { Prosentase } \\
\text { Peningkatan } \\
\mathbf{( \% )}\end{array}$ \\
\hline TRC-000 & 16748 & & \\
TRC-100 & 23478 & 6730 & 28,7 \\
TRC-150 & 28429 & 11681 & 41,1 \\
TRC-200 & 28011 & 11263 & 40,2 \\
TRC-051 & 27560 & 10812 & 39,2 \\
\hline
\end{tabular}




\begin{tabular}{llll}
\hline TRC-002 & 22053 & 5305 & 24,1 \\
\hline
\end{tabular}

Berdasarkan Tabel 5 di atas terlihat bahwa benda uji yang diberi kekangan serat cantula mengalami peningkatan secara berturut turut yaitu $28,7 \% ; 41,1 \% ; 40,2 \% ; 39,2 \%$ dan $24,1 \%$. Nilai toughness mengalami peningkatan disebabkan oleh serat cantula yang mampu menahan deformasi dan memperbesar luasan bidang bawah grafik beban - lendutan. Serapan energi yang mampu ditunjukkan oleh data-data diatas menunjukkan penggunaan serat cantula yang dianyam sebagai kekangan merupakan sebuah perkuatan alami yang sangat baik karena peningkatannya hampir meningkatkan setengah dari kuat beton normal biasa.

\section{KESIMPULAN}

Berdasarkan hasil pengujian dan pembahasan yang telah diuraikan dapat ditarik kesimpulan sebagai berikut: 1. Penggunaan serat cantula yang dianyam untuk perkuatan meningkatkan nilai daktilitas dari beton normal. Peningkatan nilai daktilitas dalam \% dari nilai terendah berturut-turut: TRC-100, TRC-150, TRC-002, TRC-200 dan TRC-051 adalah berturut-turut: 26,79\%;30\%;30,42\%;31,09\% dan 37,06\%

2. Nilai toughness mengalami peningkatan yang signifikan dalam $\%$ dari nilai terendah berturut-turut: TRC-002, TRC-100, TRC-051, TRC-200 dan TRC-150 adalah berturut-turut: 24,1\%; 28,7\%; 39,2\%; 40,2\% dan 41,1\%. 


\section{DAFTAR PUSTAKA}

Karimah dan Wahyudi. 2010. Daktilitas Kolom Beton Bertulang dengan Pengekangan di Daerah Sendi Plastis. Malang: Universitas Muhamadiyah Malang.

Kartika, Febiana Yoda. 2018. Pengarub Volume Fraction dan Aspek Rasio Serat Agave Cantula Roxb Dengan Polymer Modified Mortar Terhadap Kuat Tekan dan Kuat Tarik Langsung. Surakarta: Universitas Sebelas Maret Surakarta.

Kurniawan, Indra P. 2016. Pengaruh Temperatur Hotpress Terbadap Kekuatan Mekanik Komposit Cantula-rHDPE. Surakarta: Universitas Sebelas Maret.

Raharjo, Wijang W. 2015. Sifat Tarik dan Lentur Komposit rHDPE/Serat Cantula dengan Variasi Panjang Serat. Banjarmasin: Proceeding Seminar Tahunan Teknik Mesin XIV.

Sasmito, Ashar Natsir. 2018. Pengarub Reinforcement Ratio Serat Cantula (Agave Cantula Roxb) Terbadap Kuat Tarik Textile Reinforced Concrete. Surakarta: Universitas Sebelas Maret Surakarta.

SNI 7974-2013. 2013. Spesidikasi Air Pencampur yang Digunakan dalam Produksi Semen Hidraulis. Jakarta : Badan Standarisasi Nasional.

Tjokrodimulyo, K. 2007. Teknologi Beton. Yogyakarta : Biro Penerbit Teknik Sipil Universitas Gajah Mada.

Triputra, Katon Gilang. 2018. Proposi Optimum Polymer Modified Mortar Ditinjau Dari Kuat Tekan. Surakarta: Universitas Sebelas Maret Surakarta. 